\title{
Analysis of Institutional Change on BKAD Kanjuruhan as Organization Implementing Empowerment in Malang
}

\author{
Eko Yuni $\mathrm{P}^{1}$, M. Ismail ${ }^{2}$, A.E. Yustika ${ }^{2}$, D. Kaluge ${ }^{2}$ \\ ${ }^{1}$ Doctoral Program of Economics, Faculty of Economics \& Business, University of Brawijaya, Indonesia \\ ${ }^{2}$ Faculty of Economics \& Business, University of Brawijaya, Indonesia
}

\begin{abstract}
The concept of community development or the development of local communities (local community development) emerged as a reaction to national development-oriented power. On the other hand the implementation of various development programs using an equal approach to embed an institutional blueprint. This situation is a process called institutional monocropping for a variety of different local conditions. This study aims to explain the facts of a case study of institutional change in BKAD as an organization implementing empowerment in Kecamatan Wajak Kabupaten Malang. This study used a qualitative approach with a phenomenological method of research is organizational locus BKAD Kanjuruhan in Kabupaten Malang, East Java Province.

The results of this research in theoretical and empirical perspectives show that: (1). The results of the institutional changes during the independence period of BKAD Kanjuruhan an efficient institutional administrators deemed of interest. The institutional sustainability is a realization of the meaning of empowerment by the board as increasing the capacity of individuals in the organization and the management capacity in the capital aspect BKAD (2). BKAD board involvement to manage activities on other empowerment programs is increasing recognition of individual capacity management, (3). Availability SHU (of net income) $B K A D$ Kanjuruhan every year with ever increasing numbers indicate increasing BKAD capacity to manage capital. But in the context of the objectives of empowerment as a process of power distribution from one party to another party who does not have the power to realize, and (4). Strength in the form of funds deposited into the organization to be distributed back to that do not have it distributed to those who already have power, while also strengthening the capacity of individual reinforcement only be experienced by the group administrator.
\end{abstract}

Keywords: Institutional Change, Empowerment and Cooperation Organization Inter Village

\section{Introduction}

Poverty is still one of the priority issues to be resolved through various government development programs. One of them through various empowerment programs that have been carried out. The concept of community development or the development of local communities, emerged as a reaction to national development-oriented power. On the other hand the implementation of various development programs using an equal approach to embed an institutional blueprint. This situation is a process called institutional monocropping for a variety of different local conditions. All activities of the implementation of empowerment programs are always equipped with established agencies (organizations) are prepared to implement the new program with consideration to adjust to the demands and needs of the program.

Uphoff in Esman and Krishna (1998) explains that if the activities of the community empowerment program is only done by government or external parties only, the result will not be encouraging than if done spontaneously by local communities to engage in such activities. Thus, if empowerment is done without taking into account the institutional environment that allows the development of a bottom (bottom-up) then local communities will take action that it does not correspond to the expectations of the initiators of the program. This thesis is reinforced by Bastiaensen, et al (2005) stated that the community development programs in reducing poverty is a job that is really complex and difficult and full of risks ineffective and counterproductive. Ultimately, this leads to two scenarios, pessimistic and optimistic. Pessimistic scenario suggests that the fate of the program is almost certainly not effective in substantially change anything about the poor because of the traditional elite at the local level or the state bureaucracy as an administrator at each level behaves as the most competent or act as a broker of development, all of which was able to manipulate and exploit external intervention as if as expected by the local community. While the optimistic scenario based on the empowerment program as an effort to encourage participatory development planning (Alkire, 2002; C. Long, 2001).

Bastiaensen, et al (2005) reinforce his thesis by showing the existence of empirical facts in Cameroon with regard to local institutional dynamics triggered by Non Governmental Organization (NGO) that stimulate the production and commercialization of agriculture. Also in Nicaragua activity of local movers in micro-credit programs that serve credit for the poor. In the second case shows what happens when outside intervention met with local actors (local elite). Both in Cameroon and Nicaragua are examples of interventions that meet the local 
elite network, which impact the flow of funds earmarked for the poor eventually reproduced by local structures. This is due to misconception of implementing development programs as well as by the role of local elites to divert resources used for their own purposes.

Empowerment program by Acharya (2004) also give rise to competition between norms outside the social order and norms that have been there through the dynamic process called localization. Localization is a construction view from outside of the local actors who generate adjustments to local beliefs and practices. The process to reconstruct the practices and beliefs that have been there with the idea that comes from outside into the local context. Localization is a dynamic process in which the parties bring new norms that adjust to local beliefs and practices. In the process according to Checkel (1998), the norms of external origin which at first does not blend with the local norms subsequently merged into the local norms. The success of the strategy and deployment process of the norm depends on how far the localization capabilities of the norms from the outside. Bosch (in Acharya, 2004) describes the results of localization as a condition where in it outside mixed with the culture of the indigenous culture to form a harmony.

Localization is a form of institutional changes from the norm due to the influx of outside, where two general types of institutional change are: (1) functional areas and an increase in membership (Aggarwal, 1998; Schimmelfennig, 2001); and (2) changes in the ways in which the obligation is done, including the creation of new policy instruments (Haas, 1990), changes in procedures (Finnemore and Sikkink, 1999), validation (Goldstein, 200), and the creation of new institutions (Aggarwal, 1998). This is line with Wheatley (1982) that call institutional change with indigenous institutions or path dependency in which the options existing to form a new institution, while Aggarwal (1998) refers to it as an institutional repetition (nested institution). Options that should occur and be understood when an empowerment program implemented at the local level.

In P2SLBK program implementing organizations conducting empowerment known as the InterAgency Rural Cooperation (BKAD) which is a unit of the fund managers are in the sub-district level. BKAD is implementing empowerment organization formed with the functionality to manage the financial and construction of facilities/infrastructure that support the social and economic activities in the countryside.

Various empirical facts show that empowerment programs aim toward more obscure and turned into a seizure of goods or arena rent-seeking certain parties. Although the empowerment program monitoring and evaluation activities carried out but only limited to the preparation of the next program. his is what lead to information about healthy and unhealthy, unsuccessful and successful empowerment program becomes inaccurate. This phenomenon explained by Prasetyantoko et al (2012) that the context of decentralization in the context of poverty reduction is not yet in line with expectations. This is reinforced by a study conducted in six regions (Sukabumi, Bandung, Kebumen, Gunung Kidul, Jembrana and Makassar). The study notes that poverty reduction in six regions studied much more driven by the state-distribution through the allocation of funds. Local governments use the funds to serve people, to help finance the poor, and mobilizing community empowerment jargon. While on the other hand, local governments ignore the power of community-based local emancipation village much driven by initiative, leadership, and local movements and local potentials capable of seeding a source of collective prosperity.

Research that focuses on empowering the implementing organization raised by Aryo (2012). The results showed that since the establishment of the Institute of BMT Kube Sejahtera in 2004, some of the transformations occurring in the practice of the organization. The transformation leads to three types of institutions that are directed by the motive manager. First, BMT is driven by social motives which is close to the well-being approach, encounter problems in terms of institutional sustainability. Second, BMT is driven with a balanced motive is ideal BMT models that implement the agenda of addressing poverty and achieve selfsufficiency. Third, BMT with economic motives very well in achieving financial sustainability but left its main purpose, namely addressing poverty. It is apparent that the goal of policy makers in implementing programs for BMT Kube Sejahtera as an institution is difficult to implement poverty alleviation at the grassroots level as the prime mover in the transformation of BMT Kube Sejahtera is the motive manager, not the "blueprint" (guidelines) of BMT Kube Sejahtera and the Ministry of Social and PINBUK.

Descriptive above explains that the implementation of the development program will lead to a permanent pressure for institutional change so as to create new institutional. Institutional change can be a long adjustment to the institutional or the formation of new institutions. Changes occur as a result of gradual changes that are independent and are not aware of the existing institutions. In addition due to the influence of external factors and other stakeholders to create a new institutional. This study was not intended to test or apply the theory to the process of institutional change that occurred in the organization implementing community development programs, especially in the BKAD Kanjuruhan Kecamatan Wajak Kabupaten Malang. The expected output is to reconstruct the theory of institutional theory, especially related to community empowerment. 


\section{Kind of research}

\section{Research Methods}

The method used is the case study method. Yin (2012) states that the substance of a case study is positioned as the unit of analysis. Cases referred to in this research is the institutional changes in the implementing organization BKAD as empowerment in the Kecamatan Wajak Kabupaten Malang. The result of the case study research is a generalization of the patterns typical case of individuals, groups, institutions, and so on. Depending on the purpose, scope of the study to include a segment or a particular section or cover the life cycle of individuals, groups, and so on, both with emphasis on factors specific case, or all factors. The case study examines the variables which emphasize enough on a small number of units. This method differs from the form of the survey method, where researchers tend to evaluate fewer variables but with a relatively large sample units (Nazir, 1988).

Source of evidence-source evidence is treated the data into two categories, namely; main data and supporting data. The main data obtained from direct field recording, interviews, and observations on some actors events specifically related to the research objectives. Supporting data obtained from written documents or records, research reports and other publications.

\section{Methods of Data Analysis}

Qualitative research has two major drawbacks: (a) the researcher can not be $100 \%$ independent and neutral from the research setting, and (b) highly unstructured qualitative research (messy) and highly interpretive. Creswell and Miller in Chariri (2009) offers nine kinds of procedures to enhance the credibility of qualitative research: triangulation, disconfirming evidence, research reflexivity, member checking, prolonged engagement in the field, collaboration, the audit trail, thick and rich description and peer debriefing. In this study used triangulation. Data analysis techniques in case study research are:

a. Pairing patterns using logic pairing pattern. This logic is like comparing patterns based on empirical data with the predicted pattern (or with several alternative predictions). If this pattern there are two equations, the results can strengthen the internal validity of the case study in question.

b. Preparation of explanation, which aims to analyze the case study data by making an explanation about the case in question. Making this done narrative explanation that reflect some theoretically significant propositions.

\section{Methods of Data Validation}

According Moleong (2006) to establish the validity of the data required inspection techniques. Implementation of inspection techniques based on the criteria used is the degree of credibility, transferability, dependence (idependability), and confirmability.

a. The degree of credibility. The data collected in this study should be credible. In this study using three ways to determine the degree credibility, namely: (a) talk about it with others (peer-debriefing) (b) Triangulation and (c) negative evidence.

b. Transferability. The data and the results of this study should be applicable to other situations that are relatively equal, at least in the same context. To make the switch, the researchers tried to find and collect empirical event data in the same context. Transferability research results are usually with regard to the question: to what extent the results of the study may be published or used in any other situation. Thus researchers are expected to provide sufficient descriptive data.

c. Dependability. Dependence synonymous with reliability in quantitative research. The main tool in qualitative research is the researcher himself. The consistency of the dependency and certainty the results of research done by making a replication study.

d. Confirmability. Assurance criteria derived from the concept of objectivity in quantitative research. The data and the results of this study should be or wherever probably do not alter or relatively fixed. In a qualitative study rather difficult to qualify as a full certainty. But if this study is repeated carefully and researchers continue to consult the data findings in the field with mentors during the study period. If the results continue to produce the same or similar typology of the research is considered saturated so as to ensure the validity and objectivity of this research.

\section{Ending Research (Data Logging)}

Qualitative research is never ending because it all takes place in a turbulent and dynamic person in his life. But it appears that after us enough time so the data it will happen again. This indicates that we have entered the phase of saturation or adequacy of the data. All the new data means the data is categorized as long, if there is still a significant new category of research still may be terminated. However, due to cost and time constraints, it is usually limited to the criteria in advance.

Data logging is done when it is no longer new data, or has reached saturation so that we are ready to leave the field with a well, having farewell to officials, the elders, the subject and also to all those who have 
helped the research. Noteworthy is the community atmosphere that will be left with the impression should remain good as long as the research is in place.

The research was conducted on BKAD Kanjuruhan as implementing programs in the P2SLBK Kecamatan Wajak, Kabupaten Malang. The reason the selection of the research was based on the determination of the location of the P2SLBK which BKAD Kanjuruhan Kecamatan Wajak topped. Map of the study site can be seen on the map below.

\section{Empirical Result}

The results of this study are based on data mining in the field and connected with research methods and articulate with relevant theoretical perspectives. Substantive results of this study explain that the mechanism of Institutional Change in BKAD Kanjuruhan as Community Empowerment Program Implementing Organizations are as follows:

\section{Difference of BKAD Kanjuruhan Institutional During Assistence and Independence Period}

Pressure on institutional occurred in BKAD Kanjuruhan of future assistance until the time of the independence of this now. If the assistence period of pressure coming from the obligation to implement activities in accordance with the provisions on the independence period motivational source of pressure comes from BKAD Kanjuruhan administrators in implementing the program. It is revealed from the interview with Mr. Agus Malik, Chairman BKAD Kanjuruhan :

"In the past, almost every day we had a meeting with all the committee to plan development activities. Each of us definitely consult with an escort to be consistent with the provisions. Even the meeting until midnight. But we were all happy because although to midnight we get a transport allowance and the rest of our expenses for activities for all administrators. Anyway, if the first take care of the activities we definitely got the money. "

Statement above explained if the board BKAD Kanjuruhan interpret assistence period as a time in which all board very active role in conducting development activities in both the activities of natural resource development, human resource development and economic resources. However, different conditions they encounter when assistence period expires, the board BKAD very careful in issuing funds for routine purposes and to disburse the loan. It is as stated Ms. Riski Amalia, secretary of BKAD:

"Now we are saving money for ATK (stationery), if not essential we try not to spend money. Even for drinking water in this office alone we brought their own from home. Our loan application form sparingly so as not to print anymore. Often customers who apply for loans to photograph his own copy of the form. The savings we do because if the funds are used for purposes such BKAD is better channeled to loans in order to increase our SHU ".

One of the most important decisions agreed at the inter-village meetings forum (MAD) is the change in liability AD/ART BKAD Kanjuruhan. Changes in AD/ART was done in 2010, a year after the assistance ends and delivered by the board BKAD who later agreed to by all workshop participants. Such changes are presented in the following table.

Table 1: Changes in AD/ART BKAD Kanjuruhan

\begin{tabular}{|c|c|}
\hline AD/ART $2008-2009$ & AD/ART $2010-$ now \\
\hline $\begin{array}{l}\text { BKAD Kanjuruhan Net Profits distributed to: } \\
\text { a. BKAD capital accumulation }(35 \%) \\
\text { b. Improving the quality of human resource } \\
\text { management and community }(10 \%) \\
\text { c. Rehabilitation, and care for nature conservation or building } \\
\text { infrastructure to support the development of local resources } \\
\quad(10 \%) \\
\text { d. incentives BKAD administrators }(20 \%) \\
\text { e. Social security to the poor }(5 \%) \\
\text { f. Original revenue village }(15 \%) \\
\text { g. Returns to the partners }(5 \%) \text {. }\end{array}$ & $\begin{array}{l}\text { BKAD Kanjuruhan Net Profits distributed to: } \\
\text { a. BKAD capital accumulation ( } 40 \%) \\
\text { b. Improving the quality of human resource management and } \\
\text { community ( } 5 \%) \\
\text { c. Rehabilitation, and care for nature conservation or building } \\
\text { infrastructure to support the development of local resources } \\
(5 \%) \\
\text { d. Incentives BKAD administrators }(25 \%) \\
\text { e. Social security for the poor }(10 \%) \\
\text { f. Original revenue village }(15 \%)\end{array}$ \\
\hline
\end{tabular}

Source: AD / ART BKAD Kanjuruhan Year 2010

Compared with AD/ART before the increase in the proportion SHU used for capital accumulation BKAD Kanjuruhan become targets prioritized by the board BKAD Kanjuruhan by reducing the proportion of SHU dedicated to human resource development activities and development of natural resources. This is a form of social legitimacy BKAD obtained by the board in carrying out community development activities in the future because of the independence of the changes made to the agreement highest decision making forum, as 
specified in the formal rules. Mr. Harianto Hekky narrating the process of changing the AD/ART BKAD Kanjuruhan to researchers :

"Changes in AD/ART is we did after a visit to the comparative study of UPK Gerdu Taskin in Pamekasan. We see welfare officials there better than our equally administer government programs. After we asked to them it turns out they did change the AD/ART concerning the division of SHU. Coming home from there, I spoke with Ms. Sumiati and we both agree to submit the change to another friend. I also expressed to Mr. Sumantri and leave the decision to us. Sumiati mother who gets to deliver the change Sukoanyar village head together with sekdes pack. As for the village to Blayu and Kidangbang I ask Mr. Sumantri to convey. Finally, changes in AD / ART was agreed at MAD",

The above results can be interpreted interview that institutional is dynamic in the sense that institutional constantly evolving through interaction with other institutions and with the participants, there is a reciprocal relationship between the individual and an institutional context that both influence each other (Sjostrand, 1993). Thus the persistence of institutional not show something static. In addition, the fact that the independence BKAD during accordance with the opinion of institutional rational choice that uses functional view to see the persistence of institutional and explain the logic of instrumentality, based on the interests of actors in maximizing interests. Institutional actors will change if the institution can not achieve the ultimate goal he wanted.

Campbell (2004) provides a view of the three basic patterns of institutional change is often discussed in the flow of new institutions, namely: gradual (incremental) or evolutionary, punctuated equilibrium, and the punctuated evolution. Punctuated equilibrium describe institutional changes are disconnected, fast and deep. These types of changes can indicate a dramatic shift from one state to another state.

In the context of the institutional changes that occurred in BKAD Kanjuruhan is to follow the model of punctuated equilibrium. Assistence period with all the facilities received by BKAD Kanjuruhan an early form of institutional balance. Institutional stability during assistence period can take place because of all the interests of the actors/BKAD board in the form of rewards/incentives can accomodated. Furthermore, this balance becomes disconnected/ interrupted when the entire facilitation occurs in the form of funds and assistants drawn when the assistance period ends. Krasner (1984) mentions it as a short-term explosion of a fundamental reorganization of the static period. This period is called the period of crisis. External forces and/ or internal causes the creation or reorganization of the existing institutions. During the crisis period, these actors compare new institutional forms that can be generated. This is according to Campbell (2004) using the rational choice school, said that when certain institutions no longer function as before then the actor will make institutional changes.

The concept of tipping points and thresholds is central to understanding the institutional history of the punctuated equilibrium model of change, where a slow accumulation of pressure that eventually reaches a critical point where rapid changes occur: the path dependency based threshold models, where a relatively small movement can encourage a critical level, triggering a feedback process that leads to a more dramatic change (Pierson, 2004). Threshold concept is emphasized in the punctuated equilibrium model of change and disconnected. The basic idea is that a small shift in the above individual threshold can lead to a more significant shift in the collective behavior. Pierson judge that there is a critical point in the process of social and stout critical point can induce non-linear consequences.

Thus the mechanism of institutional changes that occurred in BKAD Kanjuruhan differed with Streeck and Thelen (2005), which puts a small adjustment is cumulative over time can generate transformative change. That happened to BKAD Kanjuruhan is the transition from assistance towards the independence period marked by fundamental institutional changes that shift the orientation of empowerment activities to economic activities that provide benefits in Perceptions board for the continuation and sustainability of the program.

This is in line with the opinion danDimaggio Powell (1991) states that once an existing institutional and standing, practices and programs will be supported by the individuals within the organization who benefit from these institutions. In this case, the power/strength plays an important role in institutional survival. In other words, there are institutions for community groups who benefit from these institutions have the power/buck to maintain the institutional.

Van de Ven and Hargrave (2004) identified four different models of institutional change, which is called the institutional design, institutional adaptation, diffusion institutional, and collective action model. In the context of the institutional changes that occurred in BKAD Kanjuruhan the institutional design of the model is a relevant model. This is because the institutional changes design institutional model focuses on intentional behavior of individual entrepreneurs involved in making or revising existing institutions to achieve its objectives. In this view, the institutional arrangements reflect an effort to pursue a conscious choice.

\section{Implications for Institutional Change at the BKAD Kanjuruhan against Community Empowerment}

The result of the institutional change of the BKAD Kanjuruhan during the independence period is an efficient institutional interest seen from the Board. The institution is a realization of the definition of the 
sustainability program of empowerment by the board as increasing the capacity of individual to organize and administrators in BKAD capacity in capital aspect. The involvement of the board BKAD to manage the activities on empowerment program to another is a form of recognition of the increasing capacity of individual board. Availability of SHU BKAD Kanjuruhan every year with an increasing number of shows the growing capacity of the BKAD in managing capital.

The fact that occurred on BKAD Kanjuruhan associated with the institutional changes of course is different from the concept of empowerment programs in the context of the P2SLBK program in the accompaniment that mandated mission of empowerment and commercial missions to the BKAD Kanjuruhan. The Mission of empowerment is actualized through the activities of natural resource development and human resources development. The development of natural resources which are needed to facilitate access to the economy, providing jobs to the poor either workmanship or in maintenance. Direct linkages between the development of natural resources with poverty can be simple, provide additional jobs when work, heighten the benefits on the market by connecting producers and consumers, workers with job opportunities, and others. While human resource development required poor due to previous choices they have made are based on bad information or less effort in using manpower and skills. While the commercial mission is is realized in the form of lending.

In addition, if a community empowerment program emphasizes the importance of the success of the program, which is marked by the change of aspects, such as an increase in knowledge and skills, a change in attitude and also behaviour that is appropriate messages delivered program. If it is the empowerment of the individual nature in the context of organizations, may not be incorrect. Especially when empowerment intended for increasing the capacity of individual board sustainable, such as organizational skills.

However, because the context is community empowerment program, there is a forgotten vital component. Referring to the opinion of Jim Ife (2002) which provides the definition of empowerment as giving power or strength to the group so that they can use in conducting action and redistribute it to parties who do not have. so they have the power to do. In this context it is clear that the empowerment process occurred in the sustainability of power distribution from one party to the other party so that all members will have the power. The fact that occurred on the empowerment program conducted by BKAD Kanjuruhan does not show this. The power of in the form of funds deposited to the organization to be redistributed to those who do not have thus distributed to parties that have had power, while strengthening the capacity of individual strengthening is also just experienced by board group only. Here, empowerment is more emphasized aspects of board's own ability to settle their own affairs.

With the condition of this kind BKAD Kanjuruhan then community empowerment has done BKAD Kanjuruhan hasn't been able to create an atmosphere or climate that allows developing community potential (enabling). The absence of BKAD activity in an effort to build the power by pushing, motivate, and raise awareness of their potentiality and will be working to expand it, to indicate it.

Furthermore, the BKAD Kanjuruhan has yet to be strengthening the potential or empowering community. This is necessary in order to more positive steps besides only providing loan. Retaining this should include concrete steps, and concerned the provision of a wide range of input and the opening of access to the wide range of opportunities that will make people become empowered.

If BKAD Kanjuruhan more emphasis on lending in the empowerment program does indeed interpret reasoned. What is a loan given to the community in small quantities or in common parlance is known as microcredit. This is because microfinance in Indonesia since long have been part of the development strategy with the assumption that the credit is very important to solve the problems of growth and poverty (Adams \& Vogel, 1997). Thus, microfinance has become a standard item in the program handling poverty implemented by the Government.

Microfinance is a provider of financial services for micro and small entrepreneurs, as well as functioning as a means of development for the rural community to covers the financial intermediation aspects and social intermediation. In addition to providing credit, microfinance has also increased the capacity of poor citizens (Ledgerwood, 1999).

In this sense, capacity and character of the poor is to be developed by BKAD Kanjuruhan beside giving access to the provision of credit. It is like being propounded Bennet and Cuevas (1996), the process of social intermediation services is not charitable in nature, there is also done with the orientation is not clear, because it is actually a process of developing a new market for the poor.

This fact shows that the grant of aid projects indirectly has created a new style of begging in the patterns community, namely by way of making the proposal solicitation assistance and send them to various agencies. Requests for help are no longer limited to urgent needs and requires enormous costs that aren't able to be provided by the community such as watering/irrigation or electricity in the village. The high expectations of the aid already extended to the real things can be done in a self directed by the community itself. Weak fighting power of society is also caused by the negative impact of government programs that are administered by third 
parties (contractors). Programs like this put position community as the audience so that it becomes accustomed to waiting for help and less feel to have the assistance provided.

Research results institutional changes in BKAD Kanjuruhan as the implementing organization empowerment program supports statement Seibel \& Parhusip (1998) that the handling of poverty programmes are implemented by the program itself and not for the sake of the poor, the program just distribute money without doing any capacity of assistence that is capable of changing the conditions of the poor.

In addition, the institutional changes of the BKAD Kanjuruhan in independence period which is solely performed with emphasis on commercial interests led to thethe poor become marginalized in the mengaksessumber funding. Non-loans and subsidies and loans with high interest selected BKAD Kanjuruhan because bringing sustainability organization while still getting a large number of customers, as stated and Seibel Parnuship (2000).

But micro-credit is often seen as the remedy of the problem of poverty. The Program not only made the instrument so that the poor have access to formal financial institutions, but more has to be a movement to empower poor communities, namely in tackling poverty, improving their quality of life and developing the skills and knowledge of the group to participate actively both in economic and social (Rajivan, 2001).

As already known, the investment in the form of financial or capital is very important for economic development. This factor is particularly prohibitive for the poor who have little or even no access at all to finance and capital. Meanwhile credit often is the missing link for a poor family who tries to maintain his life by running a small or micro enterprises. So hard to get out of the poverty trap (Panjaitan et al., 1999, Remenyi, 2000). To solve the problem above, micro-credit is required, namely to provide a capital good is intended for starting or continuing a business as small or micro enterprises increased income (income generating).

But the fact that there are in the research shows that only people who already have a business course that has more access to (or very) easy on loan, while micro enterprises especially those that run poor households often have to go bankrupt or even can not be touched because of lack of access to credit.

Implementing organizational of empowerment to community groups who have had business in favor of sustainability organizations caused the definition of empowerment in accordance with the framework of microcredit is associated with empowering described Mayoux (1998) was not able to be realized. According to Mayoux, in this context, empowerment is a term commonly used to describe the process by which people are not powerless become aware of their own situations and then updating of organising themselves collectively aimed at gaining greater access to public services as well as for the development of their economic level (Rajivan, 2001).

Thus if viewed from operationalization, then the process of empowerment by the implementing organization during the empowerment program entered independence period in the context of this research cannot carry out the primary tendency in empowerment operationalization, that carry out the process of giving or divert a portion of power, strength, or ability to society or individuals become more empowered. Implementing empowerment organization was unable to capitalize on a material asset has been built to support their independence through the development of the organization. The construction of infrastructures and means of basic physical,such as irrigation, roads, as well as activities trainingto the people who were powerless not able to optimized.

Empowerment not only includes the strengthening of individual community members, but also institutions. In stilling values of modern culture, such as hard work, thrift, openness, and accountability is the principal part of this empowerment efforts. Similarly, the renewal of the social institutions and its integration into the development activities and the role of the community in it. The most important here is the increasing popular participation in the process of decision-making concerning themselves and their society.

In addition, in terms of the secondary tendency, i.e. the tendency in the process of providing stimulation, encourage or motivate the individual to have the ability or power to determine what became of his choice through a process of dialogue also cannot be optimally carried out on the independence period.

As such research findings are inconsistent with empowerment as a view from the perspective of community development was conceived by Jim Ife (2003) that empowerment aims to improve power/the power of disadvantaged groups (poor people) in terms of public access to the resources and opportunities to participate in its management.

At the time of the BKAD Kanjuruhan mentoring functions as a tool of development for rural communities that include aspects of financial intermediation and social intermediation activities in the development of natural resources and human resources development as well as economic resources development turned into a sheer micro credit institutions only provide financial intermediation services, purely for giving loans to people who deserve a loan without doing social intermediation. This is social intermediation activities continued from simply distributing loans through micro-credit. This can be a secondary activity of the education and skills such as management training and mastery of technical skills of production and technical efforts, efforts to enhance the mastery of appropriate technology and expand its network to other markets and 
the like. All this will give stock of knowledge (in addition to the financial support that has been received through micro-credit) for the perpetrators of micro enterprises to further develop its business.

\section{Conclusion}

Refer to the description of the case study and the disclosure of institutional changes in the reality of the Kanjuruhan as BKAD implementing empowerment organization in Malang Wajak to strengthen programs of empowerment and the development of Local Resource-Based Regions (P2SLBK), then the conclusion of the results of the study as follows:

First: Result of institutional changes of BKAD Kanjuruhan during independence period is an efficient institutional interest seen from the Board. It is the institutional realization of the definition of the sustainability program of empowerment by increasing the capacity of the individual as a system operator in the association and in the aspect of capital BKAD capacity.

Second: The Involment of board BKAD to manage on empowerment program to another is a form of recognition of the increasing capacity of individual officers.

Third: Availability SHU BKAD Kanjuruhan every year with an increasing number of shows the growing capacity of the BKAD in managing capital. But in the context of the goal of empowerment as a process of distribution of power from one party to another party that does not have the power to effect.

Fourth: Power in the form of deposited funds to the Organization to be redistributed to those who do not have thus distributed to parties that have had power, while strengthening the capacity of individual strengthening is also just experienced by group administrators only.

\section{References}

[1]. Agusta, I. 2007. Aneka Metode Partisipasi Untuk Pembangunan Desa. Blogspot http://iagusta.blogspot.com/. Sosiolog Pedesaan Institut Pertanian Bogor. Di akses, 2 November 2010.

[2]. Aryo, Bagus. 2012. Tenggelam dalam Neoliberalisme? Penetrasi Ideologi Pasar Dalam Penanganan Kemiskinan. Penerbit Kepik. Depok.

[3]. Bastiaensen, Johan, Tom De Herdt and Ben D'Exelle. Poverty Reduction as a Local Institutional Process. World Development Vol. 33 No. 6, pp. 979-993.

[4]. Bungin, Burhan. 2009. Penelitian Kualitatif: Komunikasi, Ekonomi, Kebijakan Publik, dan Ilmu Sosial Lainnya. Kencana. Jakarta.

[5]. Carrol, Toby. 2010. Pembangunan Sosial Sebagai "Kuda Troya" Neoliberal Bank Dunia dan Program Pengembangan Kecamatan. Prisma Vol. 29 No. 3 Juli 2010.

[6]. Carruthers, Bruce G., 2012, Institutional Dynamics: When is Change "Real Change"?, Comparative-Historical Social Science (CHSS)Working Paper Series No. 12-004.

[7]. Chavance, Bernard. 2008. Formal and Informal Institutional Change: The Experience of Postsocialist Transformation. The European Journal of Comparative Economics Vol. 5. No. 1, pp. 57-71

[8]. Gentle, P., Thwaites, R., Race, D. \& Alexander, K. 2013, Changing role of local institutions to enable individual and collective actions for adapting to climate change, IASC2013 Abstracts: the 14th Global Conference of the International Association for the Study of the Commons, IASC, Japan.

[9]. Hargrave, Timothy J., \& Andrew H. Van De Ven, 2006, A Collective Action Model Of Institutional innovation, Academy of Management Review Vol. 31, No. 4.

[10]. Hikmat, R. Harry. 2004. Strategi Pemberdayaan Masyarakat. Humaniora Utama. Bandung.

[11]. Ife, Jim dan Tesoriero, Frank. 2008. Community Development Alternatif Pengembangan Masyarakat di Era Globalisasi. Pustaka Pelajar. Yogyakarta.

[12]. Laverack, G. 2001. An Identification and Interpretation of The Organizational Aspects of Community Empowerment. Community Development Journal. 36 (2): 40-52.

[13]. Ledgerwood, Joana. 1999. Sustainable Bangking With The Poor : Microfinance Handbook, An Institutional and Fiancial Perspective. The World Bank. Washington D.C.

[14]. Lin, Justin Yifu, 1989, An Economic Inquiry into Institutions, Cato Journal, Vol. 9, No. 1 Spring/Summer 1989.

[15]. Lyons, Michal; Carin Smuts and Anthea Stephens, 2001, Participation, Empowerment and Sustainability: (How) Do the Links Work?", dalam Urban Study2001; 38; 1233, diakses melalui http://usj.sagepub.com/cgi/ content/abstract tanggal 29 Oktober 2013.

[16]. Mansuri, Ghazala and Vijayendra Rao. 2003. Community Based (and Driven) Development: A Critical Review, Development Research Group The World Bank, November.

[17]. Miles, Matthew B., dan Huberman, Michael. 1992. Analisa Data Kualitatif, Buku Sumber Tentang Metode-Metode Baru. Diterjemahkan oleh TR. Rohidi. Penerbit Universitas Indonesia. Jakarta

[18]. Moleong, Lexi J. 2000. Metode Penelitian Kualitatif. PT. Remaja Roda Karya. Bandung.

[19]. Nunan, Fiona. 2006.Empowerment And Institutions: Managing Fisheries In Uganda. World Development.Vol. 34, No. 7, Pp. 13161332, 2006. Elsevier Ltd. All Rights Reserved.

[20]. Pakpahan, Agus. 1989. Kerangka Analitik untuk Penelitian Rekayasa Sosial: Perspektif Ekonomi Institusi. Prosiding Patanas: Evolusi Kelembagaan Pedesaan di Tengah Perkembangan Teknologi Pertanan. Pusat Penelitain Agro Ekonomi, Bogor.

[21]. Prasetyantoko, A. et al. 2012. Pembangunan Iklusif: Prospek dan Tantangan Indonesia. LP3ES. Jakarta.

[22]. Prijono, Onny S. dan A.M.W. Pranarka, ed. 1996. Pemberdayaan: Konsep, Kebijakan, dan Implementasi. CSIS. Jakarta.

[23]. Strauss, Anselm dan Corbin, Juliet. 2003. Dasar-Dasar Penelitian Kualitatif: Tatalangkah dan Teknik-teknik Teoritisasi Data. Diterjemahkan oleh Muhammad Shodiq dan Imam Muttaqien. Pustaka Pelajar. Yogyakarta.

[24]. Suharto, Edi. 2008. Kebijakan Sosial Sebagai Kebijakan Publik. Alfabeta. Bandung.

[25]. Sofianto, Arif dkk. 2009. Kajian Kapasitas dan Keberlanjutan KelembagaanProgram Nasional Pemberdayaan Masyarakat Mandiri (PNPM) Perdesaan dan Pengelolaan Keuangandi UPK. Jurnal Litbang Provinsi Jawa Tengah. Vol.7 No.2, Desember 2009. Semarang.

[26]. Soetomo.2011. Pemberdayaan Masyarakat: Mungkinkah Muncul Antitesisnya. Pustaka Pelajar. Yogyakarta.

[27]. Soekanto, Soerjono. 1990, Sosiologi Kelompok. Gramedia. Jakarta 
[28]. Stewart, A.M. 1998. Empowering People: Pemberdayaan Sumberdaya Manusia. Kanisius, Yogyakarta.

[29]. Sutopo, H. B. 2002. Metodologi Penelitian Kualitatif: Dasar Teori dan Terapannya Dalam Penelitian. Sebelas Maret University Press. Surakarta

[30]. Syahyuti. 2003.Bedah Konsep Kelembagaan: Strategi Pengembangan dan Penerapannya dalam Penelitian Pertanian. Dicetak oleh Pusat Penelitian dan Pengembangan Sosial Ekonomi Pertanian, Bogor.

[31]. Syahyuti, 2006. Konsep Penting dalam Pembangunan Pedesaan dan Pertanian. Bina Rena Pariwara. Jakarta

[32]. Thompson, John. 1995.Participatory Approaches in Government Bureaucracies: Facilitating the Process of Institutional Change. World Development. Vol. 23, No. 9, pp. 1521-1554

[33]. Tjokrowinoto, Moeljarto, 1996. Pembangunan: Dilema dan Tantangan, Pustaka Pelajar. Yogyakarta

[34]. Walizer, Michael H and Paul L. Wienir. 1990. Metode dan Analisis Penelitian. Penerjemah: Arief Sukadi Sadiman dan Said Hutagaol. Erlangga. Jakarta.

[35]. Wegerich, Kay. 2001. Determining Factors Of Local Institutional Change. In Countries In TransitionOccasional Paper No 38, Water Issues Study Group School Of Oriental And African Studies (Soas) University Of London, September, 2001

[36]. Wrihatnolo, Randy R. dan RN Dwidjowijoto, 2007. Manajemen Pemberdayaan: Sebuah Pengantar dan Panduan untukPemberdayaan Masyarakat. Elex Media Komputindo. Jakarta.

[37]. Yin, Robert, K. 2012. Studi Kasus Desain dan Metode. Penerjemah: M. Djauzi Mudzakir. Rajawali Pres. Jakarta.

[38]. Yustika, Ahmad Erani. 2006. Ekonomi Kelembagaan: Definisi, Teori, dan Strategi. Bayumedia Publishing. Malang

[39]. Yustika, Ahmad Erani dan Iwan Triyuwono (editor).2003. Emansipasi Nilai Lokal Ekonomi dan Bisnis Pascasentralisasi Pembangunan. Bayumedia Publishing. Malang 